\title{
Study on On-farm Dairy Cattle husbandry Practices in Walmera District of Oromia Regional State
}

\author{
Hirpha Ketema ${ }^{*}$ and Amanuel Bekuma ${ }^{2}$ \\ ${ }^{1}$ Holleta Poly Technique College, Ethiopia \\ ${ }^{2}$ College of Agriculture and Forestry, Mettu University, Ethiopia
}

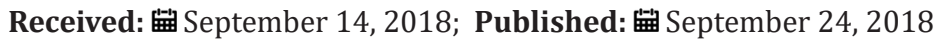

*Corresponding author: Hirpha Ketema, College of Agriculture and Forestry, Mettu University, Bedele, Ethiopia

\begin{abstract}
This study was carried out with the objective of studying on-fam dairy cattle husbandry practices in the Walmera district of Oromia regional state. The dairy cattle husbandry practices were based on field observation, questionnaire survey, focus group discussion and key informant interview. A total of 102 dairy producers were selected by using stratified random sampling technique from purposively eleven target kebeles. The survey result indicated that majorities $72.5 \%$ of household heads under investigation were male and the rest $27.5 \%$ were females. Majority of the respondents $40.2 \%$ had the family size of $7-9$ members and about $23.5 \%$ had family size more than 10 . Literacy wise, nearly half of the respondents $(46.1 \%)$ were attended elementary education (1-8 grade), whereas $31.4 \%$ illiterate and unable to read and write. The breeding method preferred and perceived as more effective for conception by respondents were natural mating (65.7\%), AI (20.6\%) and others did not identify the difference between natural mating and AI (13.7\%). Majority of respondents in the study area fed their dairy and other animals separately (80.4\%) and $19.6 \%$ of them fed all animal together. Feeding of dairy cows based on the milk yield and separately practiced by $65.7 \%$ of the respondents, while the rest were not practiced. Grazing land was decreased from year to year mainly due to urbanization and land used for crop cultivation. However, $63.7 \%$ of the farmers did not have experience to establish improved forage but only $36.3 \%$ had grown improved forage. Even if, there was no accessibility of agro-industrial by-products because of high price, shortage of supply and far distance from the source agro-industrial center, $98 \%$ of respondents were supplementing their dairy animals with agro-industrial by-products and only $2 \%$ of respondent had reported unavailability of agro-industrial by-products in the market. Bloating (44.1\%), emaciation and bloating (29.4\%) and milk fever and bloating (9.8\%) were among the most nutritional related diseases hampering dairy production in the study area. Majority $(43.2 \%)$ of the respondents were used modern barn type constructed from local materials without cattle pen. It could be concluded from the study that in the study area on-farm dairy cattle husbandry practiced by dairy producers are encouraging for future dairy development as a whole with minor improvements.
\end{abstract}

Keywords: Dairy cattle; Husbandry practice; On-farm; Walmera district

\section{Introduction}

Ethiopia, with 59.5 million heads of genetically diverse cattle, has the largest population in Africa. Cattle production plays an important role in the economies and livelihoods of farmers and pastoralists through contributing products and by-products in the form of meat, milk, honey, eggs, cheese, and butter supply etc. that are essential sources of animal protein that contribute to the improvement of the nutritional status of the people. Cattle produce a total of 3.1 billion liters of milk annually [1]. Livestock are, therefore, closely linked with the economic, social and cultural lives of millions of resource-poor farmers for whom animal ownership ensures varying degrees of sustainable farming and economic stability. In spite of the existing enormous livestock resource, the contribution of the sub sector to the agricultural production, foreign currency earnings and total GDP is not up to expectations. The potentials for increased livestock production and the productivity is proportionally lowered by various poor livestock management problems, prevalence of major endemic diseases, poor feeding and high stocking rate on grazing lands, lack of support services such as extension services, veterinary services, insufficient data to plan improved services and inadequate information on how to improve animal breeding, marketing, and processing [2].

Assessment of the cattle husbandry practices is a pre-requisite to bring improvement in cattle productivity in the country in general and in the study area in particular. Understanding of 
dairy cattle husbandry practices also helps to design appropriate technologies, which are compatible with the existing system; and to plan development and research activities and bring improvements in productivity. So far, most of the studies were limited to overall livestock management systems and carried out mainly on station; and on-farm dairy cattle husbandry practices have not fully studied yet in the study area. Therefore, it is apparent that there is a need to study on-farm dairy cattle husbandry practices in the Walmera district as a system approach to design appropriate technologies compatible with the existing system and to plan development and research activities aimed at improving dairy cattle production. Moreover, this study was also furnished essential information and experience for future dairy development efforts. Therefore, this study was intended to amplify and characterize the overall on-farm dairy cattle husbandry practices in the study area.

\section{Materials and Methods}

\section{Description of the Study Area}

The study was carried out in Walmera District of West Shoa Zone of Oromia, which is located $30 \mathrm{~km}$ to the west along the main road to Ambo. Geographically, the district is found 9 $9^{\circ} 0^{\prime} 0^{\prime \prime}-9^{\circ} 10^{\prime} 0^{\prime}$ N latitude and $38^{\circ} 25^{\prime} 0^{\prime \prime}-38^{\circ} 30^{\prime} 0^{\prime \prime}$ E longitudes. The study area has an altitude of $2400 \mathrm{~m}$. asl and receives an average annual rainfall of about $1000 \mathrm{~mm}$. The mean minimum and maximum temperatures are 6 and $22{ }^{\circ} \mathrm{C}$, respectively [3]. The mean relative humidity is 59\%. The study area obtains short rainy season (March to May), long rainy season (June to September) and dry season (October to February) [4]. The total human population of the district is 104,932 and cattle are the dominant livestock of the smallholder farmer in the area, although limited number of small ruminants and equines are kept [3]. Animals largely depend on natural grazing, which were supplemented with crop residues late in the dry season.

\section{Research Design}

Dairy cows raised under small scale production systems in the selected study sites constitute the study population. Cross-sectional type of study was conducted to collect data required for this study from 2016 to 2017 using questionnaire survey, observation and group discussion. The sampling units were defined as households keeping dairy cows.

\section{Sampling Techniques and Sample size}

Prior to conducting field survey research, discussion was conducted with the head of Walmera district livestock and fishery resource development office and dairy expert to select sites and respondents. Eleven target kebeles: two from urban area and nine kebeles from rural area were selected purposively based on the number of dairy cows that farmers own, availability of model farmers and ease of access. Sample of respondents from each selected kebeles were selected randomly using stratified random sampling technique. The numbers of respondents in each kebele was selected using proportional to size sampling approach. The sample size to collect data for this research was determined by using [5] formula:

$$
\begin{aligned}
& n=\frac{N}{1+(e)^{2}} \\
& \text { Where; }
\end{aligned}
$$

$\mathrm{n}$ = designates the sample size of the researcher uses;

$\mathrm{N}=$ designates total number of households in eleven kebeles.

$\mathrm{e}=$ designates maximum variability or margin of error $8 \%$ (0.08);

\section{$1=$ designates the probability of the event occurring}

During the study period, about 300 households in the randomly selected kebeles own dairy cows of any breeds and size.

$$
\text { Thus, } \quad n=\frac{N}{1+(e)^{2}}=\frac{300}{1+300(0.08)^{2}}=102 \text { which is the }
$$
determined sample size for the study.

\section{Methods of Data Collection and Analysis}

Both primary and secondary data sources were used for this study. Primary data were collected from respondents by pre-tested semi-structured questionnaire, key informants' interviews, focus group discussion and personal observation. Whereas, the secondary data were collected from various sources such as agricultural office, published and unpublished materials and CSA reports. The collected data from different sources were coded and recorded using Microsoft Excel spreadsheet 2007. Descriptive statistics such as frequency and percentage were used to analyze the quantitative data using SPPS version 23 software. Then the analyzed data were presented in the form of table and pie chart.

\section{Results and Discussion}

\section{Demographic Characteristics of the Respondents}

Sex, Age and Family Size: Majority of the respondents in the study area were male (72.5\%) and the rest $27.5 \%$ were females (Table 1). The highest proportion of the respondents age were ranging from 31-40 years old which accounts about $39.2 \%$, and the second highest proportion age was ranging from 41- 50 years old that accounts $27.5 \%$. Thus, the study area had relatively better potential of economically active population who could participate in dairy cattle production. Majority of the respondents (40.2\%) had the family size of $7-9$ members and about $23.5 \%$ had family size more than 10 (Table 1). From this result, it clearly could elucidate that household with more family members tended to have more labor and to adopt dairy technology than household with less family members which in turn increased milk production and then milk market participation of the households. 
Table 1: Respondent sex, age group and family size in study area.

\begin{tabular}{|c|c|c|c|}
\hline \multicolumn{2}{|c|}{ Variables } & \multirow{2}{*}{$\begin{array}{c}\text { Frequency } \\
74 \\
\end{array}$} & \multirow{2}{*}{$\begin{array}{c}\text { \% Respondents } \\
72.5 \\
\end{array}$} \\
\hline \multirow{3}{*}{ Sex } & Male & & \\
\hline & Female & 28 & 27.5 \\
\hline & Total & 102 & 100 \\
\hline \multirow{6}{*}{ Age of the respondent } & $18-30$ & 7 & 6.9 \\
\hline & $31-40$ & 40 & 39.2 \\
\hline & $41-50$ & 28 & 27.5 \\
\hline & $51-60$ & 40 & 39.2 \\
\hline & $61-70$ & 5 & 4.9 \\
\hline & Total & 102 & 100 \\
\hline \multirow{5}{*}{ Family size } & $1-3$ & 4 & 3.9 \\
\hline & $4-6$ & 33 & 32.4 \\
\hline & $7-9$ & 41 & 40.2 \\
\hline & above 10 & 24 & 23.5 \\
\hline & Total & 102 & 100 \\
\hline
\end{tabular}

\section{Education Status and Source of Labor}

Literacy wise, nearly half of the respondents (46.1\%) were attended elementary education (1-8 grade), whereas $31.4 \%$ illiterate and unable to read and write. Out of the total respondents, only 9.8\% respondents had secondary education (Figure1). Education affects the production and management of improved dairy cows; most importantly improved dairy cows breed needs high management and husbandry practices. Majority of the respondents who have crossbred dairy cows were educated from elementary up to university and have training on dairy production. Like the current result, according to [6], education levels of household heads have impacts on potential of milk production. Therefore, uneducated farmers are challenge for adoption of new technology in the development of dairy sector such as uses of AI for breeding and synchronization. The majority of the labor source of the respondents were own family labor (60.7\%), 37.3\% own family and daily labor, and only $2 \%$ were permanent employee (Figure 2). The reason may to use money paid for labor and proper farm management. This was an indication that dairy cattle management requires the attention of family members since they have high value. In line with the current result, [7] reported the same result.

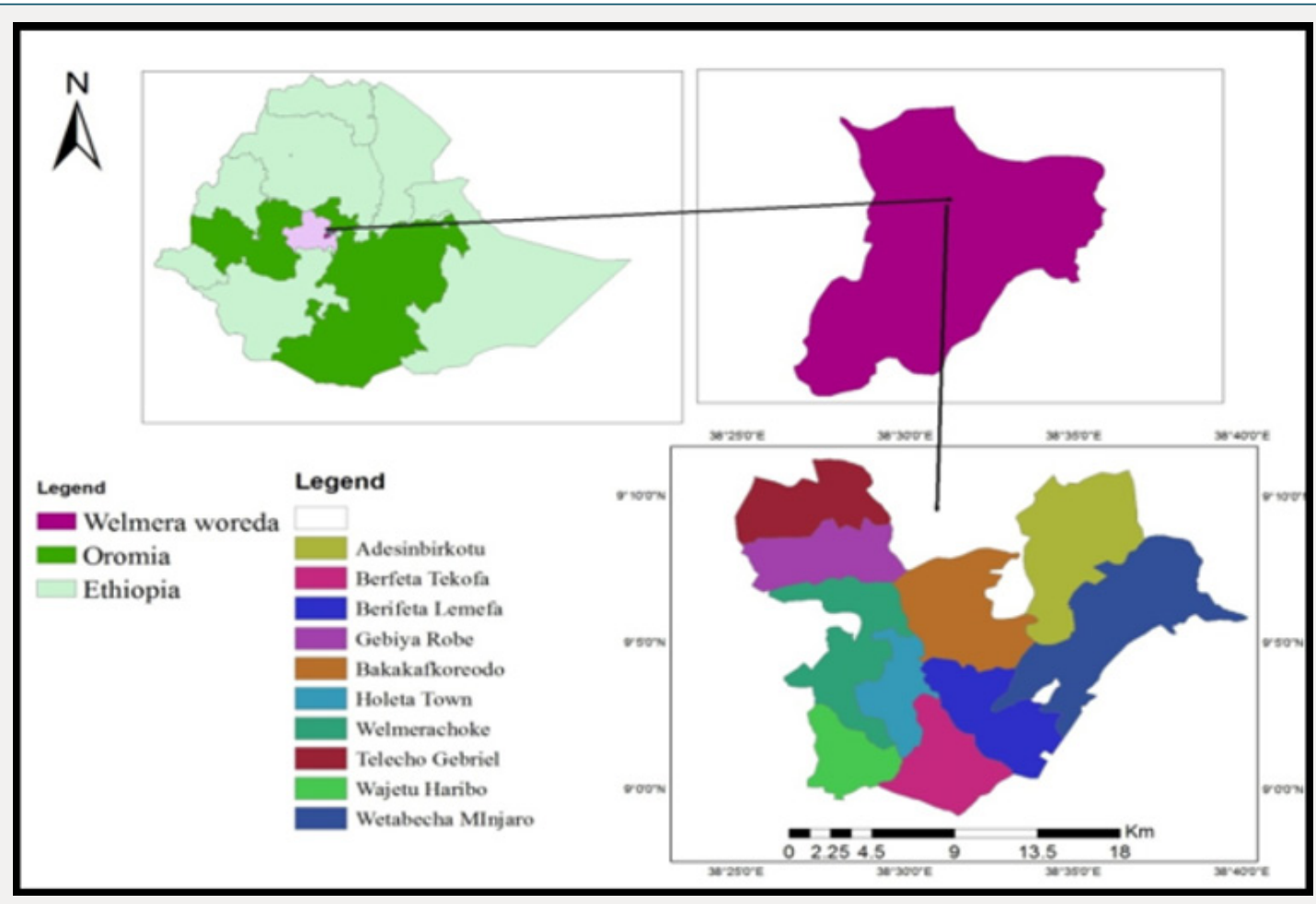

Figure 1: Map of the study area. 

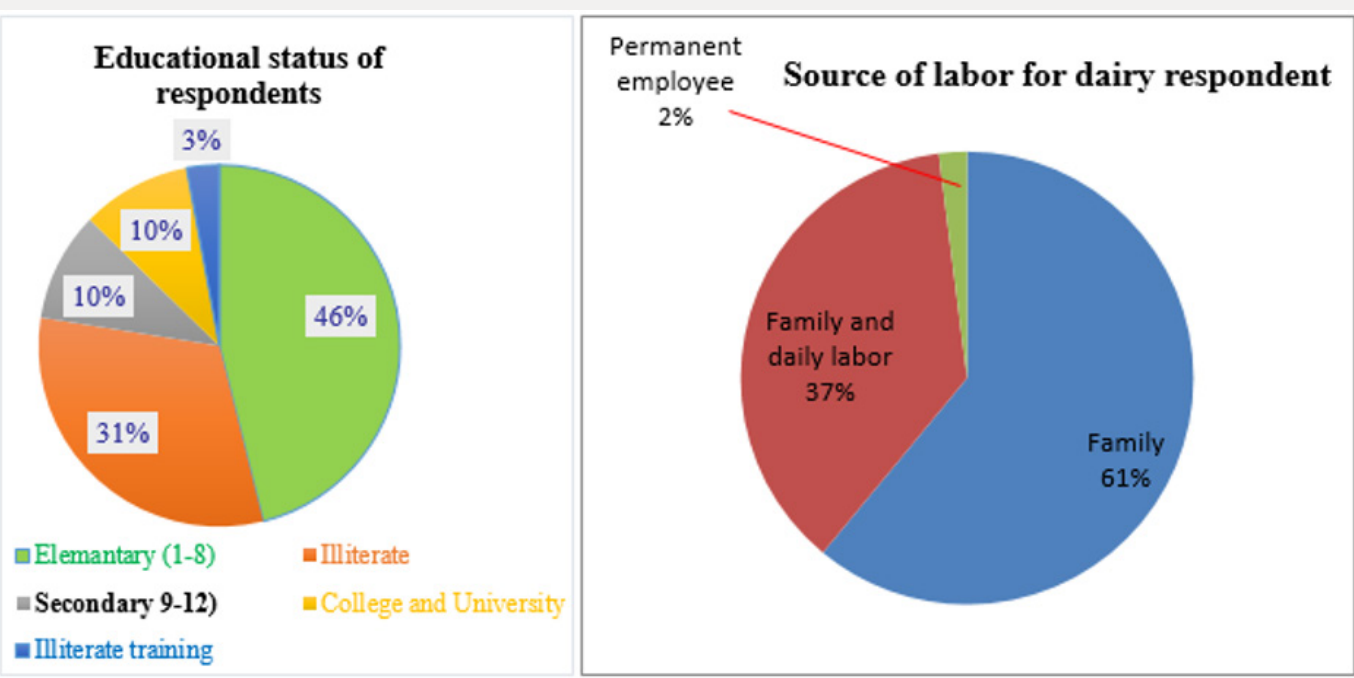

Figure 2: Educational status and source of labor of respondents for dairy in study.

\section{General Dairy Husbandry Practices}

Table 2: Source of cattle for herd establishment in the study area.

\begin{tabular}{|c|c|c|c|}
\hline \multicolumn{2}{|r|}{ Variable } & Frequency & Percent \\
\hline \multirow{4}{*}{$\begin{array}{l}\text { Owned } \\
\text { local dairy }\end{array}$} & Inherited from family & 50 & 49.0 \\
\hline & Purchased from market & 46 & 45.1 \\
\hline & No local dairy cows & 6 & 5.9 \\
\hline & Total & 102 & 100.0 \\
\hline \multirow{4}{*}{$\begin{array}{c}\text { Own } \\
\text { crossbred } \\
\text { dairy }\end{array}$} & Purchased & 56 & 54.9 \\
\hline & born on farm & 28 & 27.5 \\
\hline & From project & 18 & 17.6 \\
\hline & Total & 102 & 100.0 \\
\hline \multirow{4}{*}{$\begin{array}{c}\text { Scale of } \\
\text { dairy } \\
\text { production }\end{array}$} & $\begin{array}{l}\text { Small scale dairy producer } \\
(1-10)\end{array}$ & 54 & 52.9 \\
\hline & $\begin{array}{c}\text { Medium scale dairy } \\
\text { producer (10-20 dairy cows) }\end{array}$ & 37 & 36.3 \\
\hline & $\begin{array}{l}\text { Large scale dairy cows } \\
\qquad>20 \text { dairy cow })\end{array}$ & 11 & 10.8 \\
\hline & Total & 102 & 100.0 \\
\hline
\end{tabular}

Source of cattle for herd establishment: Majority of respondents reported that first herd establishment was made using the herd of local dairy cow inherited from family and purchased from market (Table 2). The percentage of local dairy cows inherited from family was high because of dairy cows have many roles in the socio-cultural values, like marriage and in solving disagreements. However, more of the respondents owned first crossbred dairy cattle that were purchased from market (55.9\%), born on farm $(27.5 \%)$ and from project $(16.7 \%)$. Educated farmer in study area were rearing upgraded and improved dairy cows that give high milk yield. According to the Ethiopian Standard Authority, the scale of dairy production has been set to cluster dairy producers in Ethiopia into small scale dairy producer (1-10 dairy cows) (52.9\%), medium scale dairy producer (11 to 20 dairy cows) (36.3\%) and large-scale dairy producer ( $>20$ dairy cows) $(10.8 \%)$ were dairy producer respondent interviewed.

\section{Dairy Cows Breed Preference}

In the study area, almost all of the respondents (92.2\%) preferred to keep Holstein Friesian and their cross due to their high milk production and fast growth. Whereas, $7.8 \%$ of the respondents prefer Jersey and their cross because of their higher butter yield and small body size (Table 3). In contrast, according to Sheki [13], there was no significance difference in the preference of dairy animals across Sinana by farmers. On the other hand, cattle keepers in Ethiopia prefer to select their herd based on marketable traits such as milk yield, growth rate and reproductive performances of the heifers/cows, steers/bulls. However, traits such as coat color and adaptability traditionally taken into account when selecting the dairy cattle [14] in western Oromia.

Table 3: Selection of exotic breed type and level exotic blood inheritances in the study area.

\begin{tabular}{|c|c|c|c|}
\hline \multicolumn{2}{|c|}{ Variable } & Frequency & Percent \\
\hline \multirow{3}{*}{$\begin{array}{l}\text { Preferred breed } \\
\text { types to keep }\end{array}$} & $\begin{array}{l}\text { HF and its } \\
\text { crossbred }\end{array}$ & 94 & 92.2 \\
\hline & $\begin{array}{l}\text { Jersey and it } \\
\text { crossbred }\end{array}$ & 8 & 7.8 \\
\hline & Total & 102 & 100 \\
\hline \multirow{4}{*}{$\begin{array}{l}\text { Blood Level of } \\
\text { H.F preferred }\end{array}$} & $50 \%-75 \%$ & 79 & 77.5 \\
\hline & $>75 \%$ & 2 & 2 \\
\hline & $50 \%$ & 21 & 20.6 \\
\hline & Total & 102 & 100 \\
\hline \multirow{2}{*}{$\begin{array}{c}\text { Level of } \\
\text { jersey exotic } \\
\text { inheritances }\end{array}$} & $50-75 \%$ & 8 & 7.8 \\
\hline & Total & 8 & 7.8 \\
\hline
\end{tabular}

Majority of the respondent (77.5\%) prefer 50-75\% $\mathrm{HF}$ crossbred blood level (exotic blood inheritance), $20.6 \%$ prefer $50 \%$ HF crossbred and $2 \%$ prefer more than $75 \%$ HF. A similar finding was reported by Goshu [8] Chefa farm. The author concluded that Friesian blood levels in Ethiopian dairy cattle should stabilized at a maximum of $75 \%$. In addition, in the study area for jersey 
breed all of the respondents prefer to keep 50-75\% blood level of jersey. Almost all of the farmer in the study area have $50 \%$ exotic crossbred dairy cows (kilisi) (Dikala faranji) and above 50\% (Hori Faranji). Additionally, in the study area, majority of the farmer practiced natural mating using bull with $75 \%$ exotic blood level for cross dairy cow (heifer blood level 50\%) then the next generation of heifer F2 will be above $50 \%$ exotic blood inheritance. As the focus group discussion, KII, field observation and some document from Walmera district of Livestock Development and Fishery office indicated the bull used for natural mating were HF $75 \%$ and above exotic blood level. Most of the respondents managed high exotic blood level inheritance dairy cows (50\%-75\%) were more productive. Due to majority (68.6\%) of the respondents were educated at list from short term training up to higher level and they were experienced on dairy production managing skill, knowledge, breeding methods, feeding practice, watering frequency, housing and health care practice for upgrades.

\section{Breeding Methods, Types and Source of Bull}

Table 4: Breeding method, types of bull and source of bull used for breeding in the study area.

\begin{tabular}{|c|c|c|c|}
\hline \multicolumn{2}{|c|}{ Variable } & Frequency & Percent \\
\hline \multirow{4}{*}{$\begin{array}{l}\text { Breeding } \\
\text { method } \\
\text { practiced }\end{array}$} & Natural and AI & 51 & 50 \\
\hline & Natural Mating & 47 & 46.1 \\
\hline & AI & 4 & 3.9 \\
\hline & Total & 102 & 100 \\
\hline \multirow{6}{*}{$\begin{array}{c}\text { Types bull } \\
\text { breed used for } \\
\text { natural mating }\end{array}$} & Crossbred bulls & 69 & 67.6 \\
\hline & Pure exotic bred & 22 & 21.6 \\
\hline & $\begin{array}{l}\text { Crossbred and } \\
\text { Local bull }\end{array}$ & 5 & 4.9 \\
\hline & $\begin{array}{c}\text { Not uses bull } \\
\text { only AI }\end{array}$ & 4 & 3.9 \\
\hline & Local bred bulls & 2 & 2 \\
\hline & Total & 102 & 100 \\
\hline \multirow{5}{*}{$\begin{array}{l}\text { Source of bull } \\
\text { for natural } \\
\text { Mating }\end{array}$} & From neighbor & 64 & 62.7 \\
\hline & Own Bull & 30 & 29.4 \\
\hline & $\begin{array}{c}\text { Uncontrolled } \\
\text { mating }\end{array}$ & 4 & 3.9 \\
\hline & only uses AI & 4 & 3.9 \\
\hline & Total & 102 & 100 \\
\hline
\end{tabular}

Two types of breeding method, natural mating and AI were mainly practiced in the study area. Bulls used for two main types of natural mating either for uncontrolled mating (free mating) or controlled mating. In uncontrolled mating, the bull carries out heat detection and cows in heat were mated during each heat period. In controlled mating systems, the farmers carry out heat detection and timing of service, and each cow mated once or twice during each heat period. In addition, for AI the farmers carry out heat detection and timing of service and each cow inseminated once or twice during each heat period. Most of the farmers in the study area bred their dairy cows using natural mating and AI (50\%), natural mating (46.1\%) and only AI (3.9\%) (Table 4). In contrast to this, Blen [9] reported dairy producers bred their animals using artificial insemination (89.0\%) and few use natural method (bull) $(11.0 \%)$ in Bishoftu. Besides, dairy producers were used crossbred bull (68.6\%), pure exotic (21.5\%), crossbred and local bull (4.9\%), only AI service (3.9\%) and local bull breed (2\%) for breeding. The source of bulls was from neighbors (62.7\%), uses own bull (29.4\%), and uncontrolled mating (3.9\%) (Table 5).

Table 5: Types of feeds and feeding practice of dairy cows in the study area.

\begin{tabular}{|c|c|c|c|}
\hline \multicolumn{2}{|c|}{ Variable } & Frequency & Percent \\
\hline \multirow{4}{*}{$\begin{array}{c}\text { Types feed } \\
\text { Basal diet feed }\end{array}$} & $\begin{array}{c}\text { Roughage and } \\
\text { concentrate }\end{array}$ & 102 & 100 \\
\cline { 2 - 4 } & $\begin{array}{c}\text { Grazing pasture, } \\
\text { hay and straw }\end{array}$ & 80 & 78.4 \\
\cline { 2 - 4 } & Hay and Straw & 22 & 21.6 \\
\cline { 2 - 4 } & Total & 102 & 100 \\
\hline \multirow{2}{*}{$\begin{array}{c}\text { Fed dairy and } \\
\text { other animals } \\
\text { separately }\end{array}$} & Yes & 82 & 80.4 \\
\cline { 2 - 4 } & Total & 102 & 19.6 \\
\hline \multirow{2}{*}{$\begin{array}{c}\text { Feeding based } \\
\text { on MY }\end{array}$} & Yes & 67 & 100 \\
\cline { 2 - 4 } & Total & 102 & 65.7 \\
\cline { 2 - 4 } & & 35 & 100 \\
\hline
\end{tabular}

MY=Milk Yield

\section{Breeding Method Preference, Ai Service Provision and Accessibility in Study Area}

On-farm breeding methods preferred by small scale dairy producers in the study area were depicted in (Figure 3). Even if, AI offers several advantages over the natural service, it was not found to be as effective and efficient as that of natural mating. AI is a means of genetic improvement, cost effectiveness, disease control, safety breeding, flexibility, and fertility management [7]. However, AI includes poor conception rate due to poor heat detection and inefficiency of AI technicians, dissemination of reproductive diseases and poor fertility rates, if $\mathrm{AI}$ centers are not equipped with appropriate inputs and are not well managed [8]. In the study area, due to similar reason most of the respondents prefer natural mating. All the respondents repeatedly told that most of the AI service provided by the government technician was not easily accessible for the farmers. In the current study, only $24.5 \%$ of the respondents had easy access to AI service and the rest did not have easy access to AI service; hence government should design strategies to address the interest of the farmers [10]. 


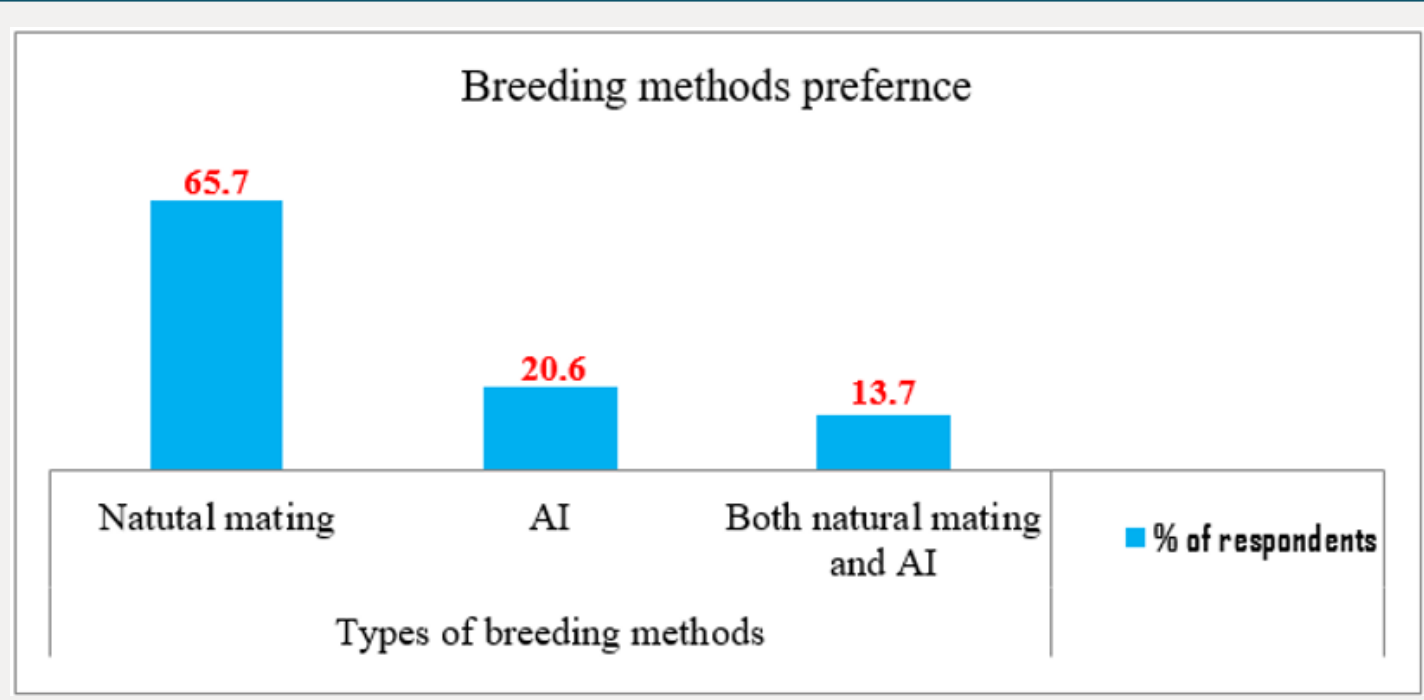

Figure 3: Breeding methods preference by dairy producers in the study area.

\section{Animal Feeds and Feeding Practice}

All of respondents feed their cows both roughage and agroindustrial by-products (concentrate) (Table 6). The respondents feed roughage like grazing pasture, hay and straw (78.4\%) as basal diet for dairy cows. Similar finding was reported by Mustefa [11] in Sululta and Walmera districts. The major feed resources identified were native pasture, crop residues, agro- industrial by-products; few fodder crops (oats and vetch mixture). Majority of respondents in the study area fed their dairy and other animals separately $(80.4 \%)$ and $19.6 \%$ of them fed all animal together. Feeding of dairy cows based on the milk yield and separately practiced by $65.7 \%$ of the respondents, while the rest were not feeding their dairy cows based on their milk yield.

Table 6: Grazing land status and establishment of improved animal forage in study area.

\begin{tabular}{|c|c|c|c|}
\hline \multicolumn{2}{|c|}{ Variable } & Frequency & Percent \\
\hline $\begin{array}{c}\text { Grazing Land } \\
\text { Status }\end{array}$ & Decreasing & 102 & 100.0 \\
\hline \multirow{2}{*}{$\begin{array}{c}\text { Experience to } \\
\text { grow improved } \\
\text { Forage }\end{array}$} & No & 65 & 63.7 \\
\cline { 2 - 4 } & Tes & 37 & 36.3 \\
\hline \multirow{4}{*}{$\begin{array}{c}\text { Utilize } \\
\text { improved forage }\end{array}$} & Not established & 102 & 100.0 \\
\cline { 2 - 4 } & Grazing, CCS & 22 & 63.7 \\
\cline { 2 - 4 } & CCS & 15 & 21.6 \\
\cline { 2 - 4 } & Total & 102 & 14.7 \\
\hline
\end{tabular}

$\mathrm{CCS}=$ Cut and Carrying system .

\section{Grazing Land and Establishment of Improved Animal Forage}

In the present study, grazing land was decreased from year to year in the study areas. However, $63.7 \%$ of the farmers did not have experience to establish improved forage but only $36.3 \%$ had grown improved forage (Table 7). Majority of the respondents who had experience to grow improved forage, they utilize the forage through grazing the animal directly along with cut and carry system $(21.6 \%)$ and cut and carrying system alone (14.7\%).

Table 7: Cropping season, way of storing and the common crop residues in study area.

\begin{tabular}{|c|c|c|c|}
\hline \multicolumn{2}{|c|}{ Variable } & \multirow{2}{*}{$\begin{array}{c}\text { Frequency } \\
102\end{array}$} & \multirow{2}{*}{$\begin{array}{c}\text { Percent } \\
100\end{array}$} \\
\hline Cropping season & Once & & \\
\hline \multirow{3}{*}{ Store crop residues } & $\begin{array}{c}\text { Stacked under } \\
\text { shed }\end{array}$ & 93 & 91.2 \\
\hline & Stacked out side & 9 & 8.8 \\
\hline & Total & 102 & 100.0 \\
\hline \multirow{3}{*}{$\begin{array}{l}\text { Types of common } \\
\text { crop residues }\end{array}$} & $\begin{array}{c}\text { Barley, wheat, } \\
\text { teff }\end{array}$ & 65 & 63.7 \\
\hline & $\begin{array}{l}\text { Barley, wheat, } \\
\text { oat }\end{array}$ & 37 & 36.3 \\
\hline & Total & 102 & 100.0 \\
\hline
\end{tabular}

\section{Common Types of Crop Residues and Way of Storing}

There was only one cropping season in study area and then the crop residues produced only once year. Almost all of the respondents $(91.2 \%)$ in the study area properly store crop residues under shade while the few (8.8\%) stored outside without shade (Table 8). The most common type of crop residues used for animal feed in the study area were barley, wheat and teff straw (63.7\%), and barley, wheat and oat straws (36.3\%). According to Mohammed [12] in Jimma Zone, crop residues were the second feed resources for livestock followed by wild browse/fodder trees and shrubs, crop thinning, weeds, and non-conventional feeds including household left over. 
Table 8: Supply agro-industrial by product, feed during milking and add salt in the study area.

\begin{tabular}{|c|c|c|c|}
\hline \multicolumn{2}{|c|}{ Variable } & \multirow{2}{*}{$\begin{array}{c}\text { Frequency } \\
102\end{array}$} & \multirow{2}{*}{$\begin{array}{c}\text { Percent } \\
100.0\end{array}$} \\
\hline $\begin{array}{l}\text { Supply Agro- } \\
\text { industrial by- } \\
\text { product }\end{array}$ & Yes & & \\
\hline \multirow{4}{*}{$\begin{array}{l}\text { Frequency of } \\
\text { supply Agro- } \\
\text { industrial } \\
\text { by-product per } \\
\text { day }\end{array}$} & Twice & 62 & 60.8 \\
\hline & Three & 38 & 37.3 \\
\hline & Four & 2 & 2.0 \\
\hline & Total & 102 & 100.0 \\
\hline $\begin{array}{l}\text { Affordability of } \\
\text { Agro industrial } \\
\text { by-product }\end{array}$ & No & 102 & 100.0 \\
\hline \multirow{3}{*}{$\begin{array}{l}\text { Problem of } \\
\text { accessibility }\end{array}$} & $\begin{array}{l}\text { High price, } \\
\text { shortage on } \\
\text { market and far } \\
\quad \text { source }\end{array}$ & 100 & 98.0 \\
\hline & $\begin{array}{c}\text { Shortage on } \\
\text { market }\end{array}$ & 2 & 2.0 \\
\hline & Total & 102 & 100.0 \\
\hline \multirow{3}{*}{$\begin{array}{l}\text { Feed during } \\
\text { milking }\end{array}$} & No & 69 & 67.6 \\
\hline & Yes & 33 & 32.4 \\
\hline & Total & 102 & 100.0 \\
\hline $\begin{array}{l}\text { Add salt to } \\
\text { dairy feed }\end{array}$ & Yes & 102 & 100.0 \\
\hline
\end{tabular}

\section{Feeding Agro-Industrial by Products}

As the survey result indicated in study area, all the respondents supply agro- industrial by-products for their animals (Table 9). Even if, there was no accessibility of agro-industrial by-products because of high price, shortage of supply and far distance from the source agro-industrial center, $98 \%$ of respondents were supplementing their dairy animals with agro-industrial by-products and only $2 \%$ of respondent had reported unavailability of agro-industrial byproducts in the market. In contrast to Mohammed [12] reported for Jimma zone, none of the household use agro-industrial by products as a potential concentrate for livestock feeds. About $88.15 \%$ of the respondent households reported high cost of agro-industrial byproducts as the main limiting factors not to use it as livestock feeds while lack of awareness on use of agro-industrial by-products as livestock feed was reported by $5.93 \%$ of the respondents. About $5.93 \%$ of the households reported that all agro-industrial byproducts were produced in a distant area. In study area, most of the respondents $(60.8 \%)$ supply agro- industrial by product twice per day, $37.3 \%$ of the respondents supply three times per day, and $2 \%$ of them were supply four times day. In the study area, almost all of the respondents also provide table salt and bole (Amole) as minerals supplement. Similarly, Sheki [13] reported the findings in Sinana district of Bale zone.
Table 9: Respondent Health Care practice, Vaccinate, Deworm and Spray in the study area.

\begin{tabular}{|c|c|c|c|}
\hline \multicolumn{2}{|c|}{ Variable } & Frequency & Percent \\
\hline \multirow{7}{*}{$\begin{array}{l}\text { Common dairy } \\
\text { cows Nutrition } \\
\text { related disorder }\end{array}$} & Bloating & 45 & 44.1 \\
\hline & $\begin{array}{l}\text { Emaciation and } \\
\text { bloating }\end{array}$ & 30 & 29.4 \\
\hline & Emaciation & 10 & 9.8 \\
\hline & $\begin{array}{l}\text { Milk fiver and } \\
\text { bloating }\end{array}$ & 10 & 9.8 \\
\hline & Milk fever & 4 & 3.9 \\
\hline & No one & 3 & 2.9 \\
\hline & Total & 102 & 100.0 \\
\hline $\begin{array}{l}\text { vaccinate } \\
\text { animals }\end{array}$ & Yes & 102 & 100 \\
\hline \multirow{4}{*}{$\begin{array}{c}\text { Types of } \\
\text { disease Animal } \\
\text { vaccinated }\end{array}$} & $\begin{array}{c}\text { CBPP, FMD, } \\
\text { Pasteurellosis } \\
\text { and black leg }\end{array}$ & 85 & 83.3 \\
\hline & $\begin{array}{l}\text { Black leg, } \\
\text { anthrax and } \\
\text { FMD }\end{array}$ & 11 & 10.8 \\
\hline & FMD & 6 & 5.9 \\
\hline & Total & 102 & 100 \\
\hline \multirow{3}{*}{ Deworm animal } & Yes & 100 & 98 \\
\hline & No & 2 & 2 \\
\hline & Total & 102 & 100 \\
\hline \multirow{3}{*}{ Spray animal } & Yes & 53 & 52 \\
\hline & No & 49 & 48 \\
\hline & Total & 102 & 100 \\
\hline \multirow{3}{*}{$\begin{array}{l}\text { Frequency of } \\
\text { spray per year }\end{array}$} & $\begin{array}{c}\text { External } \\
\text { parasite occurs }\end{array}$ & 92 & 90.2 \\
\hline & Twice per year & 10 & 9,8 \\
\hline & Total & 102 & 100 \\
\hline
\end{tabular}

\section{Source of Water and Frequency of Watering Dairy Cows}

In the study area, the sources of drinking water and frequency of watering were depicted in Figure 4. During the dry season $16.7 \%$ of farmers were get water from well. From the result, in the study area, it could understand that there was no problem of drinking water.

\section{Health Care Practice}

In the study area most, common nutritional related disease occur was bloating (44.1\%) that the respondent facing on the farm, emaciation and bloating (29.4\%), emaciation (9.8\%), milk fiver and bloating (9.8\%), milk fiver $(3.9 \%)$ and $2.9 \%$ of the respondents reported that they were not face any nutrition related disease (Table 10). All of the respondents in the study area were vaccinate their animals for different types of disease. About $83.3 \%$ of the respondents vaccinate their animal for disease like CBPP, FMD, Pasteurellosis and black leg, and about $10.8 \%$ for black leg, anthrax and FMD and about 5.9\% FMD. Almost all of the respondents dewarm their animal (98\%) and the remaining $2 \%$ were not de-warm 
and those spray their animals were $48 \%$. Most of the respondent spray their animal during prevalence of external parasites $(90.2 \%)$ and $9.8 \%$ of the respondent practice spraying twice a year in the April and May. This health control practices in the study areas could contribute for effective dairy production. Market oriented smallholder dairy farms have access to veterinary services due to the income they get from the sale of milk that enable them to cover veterinary costs.

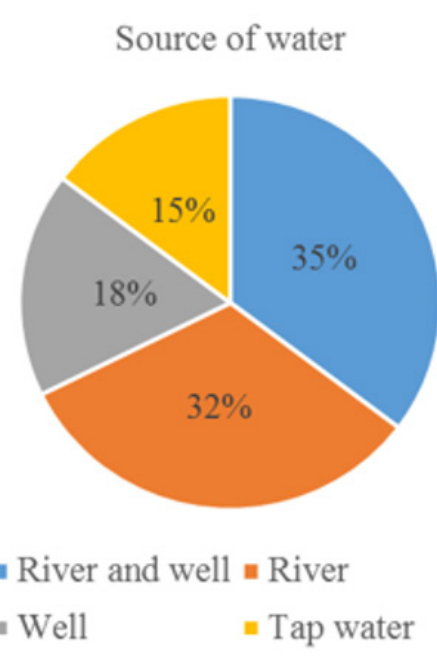

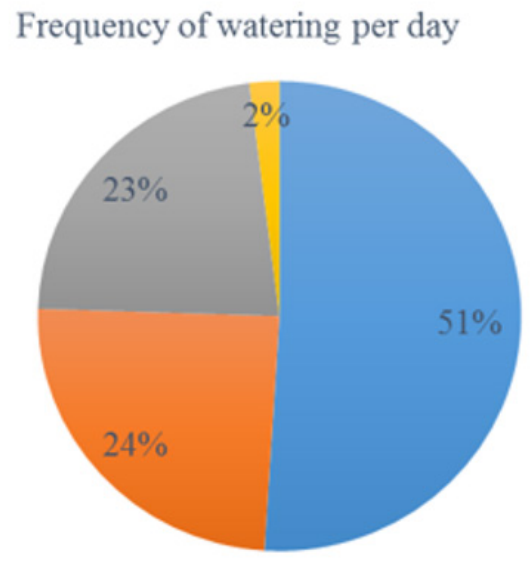

awice $\square$ Three $₫$ Once $=$ Adlib

Figure 4: Source of water and frequency of watering dairy cows per day.

Table 10: Type of house and house comfort for dairy cows in Walmera district.

\begin{tabular}{|c|c|c|c|}
\hline \multicolumn{2}{|r|}{ Variable } & Frequency & Percent \\
\hline \multirow{5}{*}{ Type of house } & MBLM without individual cattle pen & 44 & 43.1 \\
\hline & Modern barn with individual cattle pen & 25 & 24.5 \\
\hline & Traditional barn with partition & 19 & 18.6 \\
\hline & Traditional barn (Free stall) & 14 & 13.7 \\
\hline & Total & 102 & 100.0 \\
\hline \multirow{3}{*}{ Have maternity (CP) } & Yes & 54 & 52.9 \\
\hline & No & 48 & 47.1 \\
\hline & Total & 102 & 100 \\
\hline \multirow{4}{*}{ Type of Floor } & stone building & 41 & 40.2 \\
\hline & Concrete & 39 & 38.2 \\
\hline & Ground & 22 & 21.6 \\
\hline & Total & 102 & 100.0 \\
\hline \multirow{4}{*}{ Type of roof } & Rain proof by corrugated iron & 68 & 66.7 \\
\hline & $\begin{array}{l}\text { Rain Proof by local available Material (straw, hat } \\
\text { and dry grass) }\end{array}$ & 32 & 31.4 \\
\hline & Not rain proof & 2 & 2.0 \\
\hline & Total & 102 & 100.0 \\
\hline
\end{tabular}

\section{Housing System}

In the study area, all of the respondents house their animal in different types of houses. About $43.1 \%$ of the respondents were used modern barn type constructed from local material without individual cattle pen, $24.5 \%$ modern barn with individual cattle pen, $18.6 \%$ traditional barn with partition and $13.7 \%$ traditional barn (free stall). Similar results were reported by Mustefa [11] in Sululta and Walmera districts. Currently the types of roof the respondents in Walmera district had rain proof corrugated iron
(66.7\%), rain proof by local material covered $(31.4 \%)$ and $(2 \%)$ not rain proof barn. The floor types were built by stone $(40.2 \%)$, concert (32.6\%) and earthen floor (21.6\%). This showed that there were many improvements in the dairy production system in the district [14].

\section{Conclusion and Recommendation}

It could be concluded from the study that in the study area on-farm dairy cattle husbandry practiced by dairy producers are 
encouraging for future dairy development as a whole with minor improvement on breeding strategies, identifying types of feeds along with types of dairy cows to be fed, and deep awareness and training on most nutritional related diseases. Therefore, appropriate intervention in nutritional related diseases and prevention activities, breed improvement strategies, deep and regular training on basic principle of animal feeds and feeding are highly recommended so as to improve sustain productivity of dairy cows and being benefited from the existing market and high demand of products.

\section{Acknowledgement}

We would like to admit the Walmera District livestock development and Fishery Office heads and staff members for their cooperation. Development agents and respondent farmers in respective kebeles, who directly or indirectly participate during data collection, are highly acknowledged.

\section{References}

1. CSA (Central Statistical Authority) (2017) Federal democratic republic of Ethiopia, central statics agency, agricultural sample survey: report of livestock and livestock characteristics. Addis Ababa, Ethiopia.

2. Kedija Hussen, Azage Tegegne, Mohammed Yousuf Kurtu, Berhanu Gebermedhin (2008) Traditional cow and camel milk production and marketing in agro pastoral and mixed crop livestock systems: The case of Mieso District, Oromia Regional State, Ethiopia. IPMS (Improving Productivity and Market Success) of Ethiopian Farmers Project Working Paper 13. ILRI (International Livestock Research Institute), Nairobi, Kenya, pp. 9-42.

3. Walmera District Livestock Development and Fishery Office (2017) Annual work report: Unpublished.

4. Holeta Agricultural Research Center (2008).

5. Yamane T (1967) Statistics an Introductory Analysis, (2 $2^{\text {nd }}$ edn.), Harper and Row, New York, USA.

6. Lemma HD, Mengistu Alemayehu, Kuma T, Kuma BB (2017) The potential of milk production and Consumption consumption for improving nutrition of smallholder dairy households in Ethiopia. Indicated, Wolaita Sodo University, Wolaita Sodo, Ethiopia Addis Ababa University, College of Veterinar Medicine and Agriculture, Ethiopia. Ethiopian Development Research Institute, Ethiopia.

7. Gillah KA, Kifaro GC, Madsen J (2012) Urban and pri-urban dairy farming in East Africa: A review on production levels, constraints and opportunities Ministry of Livestock Development and Fisheries. Dares Salaam Tanzania Department of Animal Science and Production, Sokoine University of Agriculture, Morogoro Tanzania Department of Large Ruminants, University of Copenhagen. Livestock Research for Rural Development 24(11): 198.

8. Goshu Gebeyehu (2005) Breeding efficiency, lifetime lactation and calving performance of Friesian-Borancrossbred cows at Cheffa farm, Ethiopia. Livestock research for Rural Development, 17: (7).

9. Blen Merid (2016) Assessment of major reproductive health problems, their effect on reproductive performance and association with brucellosis in dairy cows in Bishoftu town, Ethiopia. MSc. Thesis presented to Addis Ababa university, college of veterinary medicine and agriculture, department of animal production studies Bishoftu, Ethiopia.

10. Holm DE, Thompson PN, Irons PC (2008) The economic effects of an estrus synchronization protocol using prostaglandin in beef heifers. Theriogenology, 70: 1507-1515.

11. Mustefa Abu Kuffa (2012) Value Chain And Quality Of Milk In Sululta And WalmeraWalmera Weredas, Oromia Special Zone Surrounding Addis Ababa, Oromia, Ethiopia. College of Veterinary Medicine and Agriculture Addis Ababa University.

12. Mohammed Husen, Yisehak Kechero, Meseret Molla (2016) Assessment of Livestock Feed Resources Utilization in Jimma Zone, Southwest Ethiopia. Academic Journal of Nutrition 5(1): 1-17.

13. Sheki Yasar, Tekleab Serakeberhan, Ermias TTsadik, Girma Defar et al. (2016) The husbandry practices of dairy cattle, feed resources, and dairy products processing and marketing in Sinana District of Bale Zone, Oromia Region, Ethiopia. Department of Animal and Range Sciences, Madda Walabu University, Bale-Robe, Ethiopia. International Journal of Livestock Production 7(11): 113-121.

14. Ayantu Mekonnen, Ayenalem Haile, Taddele Dessie, Yosef Mekasha (2012) On farm characterization of Horro cattle, breed production systems in western Oromia, Ethiopia. Livestock Research for Rural Development 24(2012): 100.
To Submit Your Article Click Here: Submit Article

DOI: $10.32474 / C I A C R .2018 .04 .000195$
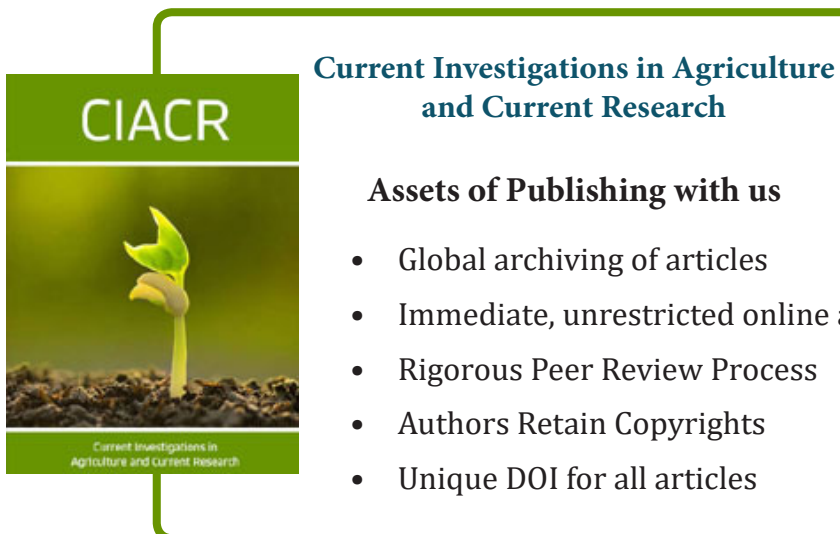

Assets of Publishing with us

- Global archiving of articles

- Immediate, unrestricted online access

- Rigorous Peer Review Process

- Authors Retain Copyrights

- Unique DOI for all articles 